ISSN 0975-3311

Ushus JBMgt, 9, 2 (2010) 31-49

ISSN 0975-3311 | https://doi.org/10.12725/ujbm.17.3

\title{
Indian MNCs in the Tempest of Global Businesses
}

\author{
Arup Barman*, Ranjit Singh ${ }^{* *} \&$ Juthika Konwar ${ }^{* * *}$
}

\section{ABSTRACT}

Prior to liberalization of economy India could not feel the taste of operating business globally as of today. Today, many Indian companies are now known for its global operations, competitiveness, and for their global concerns. But, these are not equally applicable to all MNCs. Hence, the question arises; do all MNCs play similarly to have their global presence? In the tempest of the global business how Indian MNCs are demonstrating their global presence needs clear understanding.

The present paper aims to appreciate 'Indian MNCs in the tempest of global businesses'. The paper attempts to achieve three objectives, they are- to highlight on the state of domestic and overseas presence of selected companies; to examine the similarity vs. dissimilarity of consciousness and directions of corporate readiness for future; to

* Dept. of Business Administration, Assam University, Silchar-788011, Email : arupgeet@rediffmail.com.

**Dept. of BusinessAdministration, Assam University, Silchar-788011,Email : look_for_raniit@yahoo.co.in.

*** Dept. of Business Administration, Assam University, Silchar-788011,Email : juthika_konwar@yahoo.com 
examine the convergence and divergence of core business development strategies of observed corporations.

The top Indian global corporations having overseas presence are considered as universe of the study; and 16 numbers of MNCs is the sample for final analysis. The study deployed exploratory research design, desk and text research based on the reviews of qualitative and quantitative information published either in records/reports or journals/ magazines.

Key words: Strategic Cores, Global Consciousness, Domestic and Overseas Presence.

\section{Introduction}

Recent years were years of challenges and volatile markets in the backdrop of uncertainty in the global commodity market, financial market crisis in US and the emanating global cash liquidity issues thereof. This has been a turbulent year. The sub-prime crisis that erupted in the US and Western Europe impacted the global financial system, resulting in a significant cutback in investment flows and availability of funds. The developing world continued to enjoy growth in its demand for goods and services, contributing to the global inflationary trends in oil, coal, minerals and other commodities. The cost of food similarly rose in several countries during the latter part of the year, leading to unrest and hardship amongst the poorer nations. Some governments have lately begun to impose anti-inflationary measures on their over-heated economies to curb runaway price increases and consumption. In this business vortex Indian MNCs have been operating not in isolation with other global players.

On the hand intense global competition and rapid growth are forcing Indian firms to examine corporate enterprise risk management (ERM) to identify, assess and respond to the social, political and economic risks of doing business. A new Conference Board study, sponsored by KPMG India and SAP India, examines the state of risk management integration in companies based in India, and includes case studies of four major Indiabased multinational firms: Tata Motors Ltd, IClCl Bank, Tata Chemicals Ltd., and Dr. Reddy's. Senior Research Associate at The Conference Board Governance Center, and a co-author of the report "As Indian firms expand beyond national borders, they become exposed to more strategic and 
operational risks, including those from different geopolitical and cultural contexts. Tightening capital markets, the internationalization of successful Indian companies and the adoption of global initiatives to promote business integrity are forcing many firms to pay attention to recent developmental and business blizzards around the globe. Assimilating international standards of risk management is becoming a necessity to remain competitive". According to Poonam Barua, Regional Director - India, The Conference Board, stated that as Indian companies begin to grow globally, they will need to increasingly view beyond financial issues and must address the areas such as managing high growth, business execution, innovation, talent retention, succession planning, industrial safety and environment change, and related issues. Recent events have shown that various high performing companies have suddenly gone under," The indications are clear, Indian mega-corps as well as MNCs might have been responding to the dimensions, but how, whether all firms responding in the similar or dissimilar way, are the questions need answer. Hence, authors of this paper framed three objectives to address the issues in the context of Indian MNCs.

\section{Objectives of Study}

1. To highlight the state of domestic and overseas presence of selected Indian MNCs;

2. To examine the similarity vs. dissimilarity of consciousness and directions of readiness for future among Indian MNCs;

3. To examine the convergence and divergence of core strategies of observed corporations.

\section{Methodology}

The study deployed exploratory research design based on desk-research methodology which includes review of qualitative and quantitative information published either in the records/reports or journals/magazines. Top Indian global corporations having overseas presence are considered as the universe of the study. From the top Indian global companies numbers of companies having the position as the best wealth creator are considered as the sample in this study. 


\section{Economic and Geographic Spread}

The geographic and economic spreads of the Indian MNCs are witnessing appreciable growth. The spread of technology and pharmaceutical sectors are considerably wider. The iron and steel and aluminium sector's corporations are showing the largest spread. The energy sectors corporations spread is at the growing stage as evidenced from the annual reports. The table- 2 indicates the continental as well as global presence of these MNCs in the blizzard of sectoral business of the globe.

Table-1: Continental and Global Presence

\begin{tabular}{|c|c|c|}
\hline SL.No. & Company & Overseas Operation of Business \\
\hline 1 & Reddy's Lab & $\begin{array}{l}\text { Sri Lanka, Russia, Ukraine, Belarus, Kazakhstan, } \\
\text { Uzbekistan, China, UAE, Brazil, Malaysia, South } \\
\text { Africa, USA, UK, Kenya, Uganda, Tanzania, Ghana, } \\
\text { Mauritius, Dominican Republic, Haiti, Romania, } \\
\text { Albania, Vietnam, Cambodia, Myanmar, Singapore, } \\
\text { Venezuela, Trinidad, Jamaica, Germany, Mexico, } \\
\text { Switzerland, Spain }\end{array}$ \\
\hline 2 & Ranbaxy & $\begin{array}{l}\text { North America, USA, Canada, UK, France, Spain, } \\
\text { Germany, Poland, Romania, Italy, Latin America, } \\
\text { Japan, South Africa, Russia, China, European Union, } \\
\text { Sweden Brazil, ASEAN }\end{array}$ \\
\hline 3 & Sun Pharma & $\begin{array}{l}\text { Asia, South East Asia, Russia, China, the Middle } \\
\text { East, Latam and Africa, US }\end{array}$ \\
\hline 4 & Crompton Grieves & $\begin{array}{l}\text { Hungary, Ireland, UAE, USA, Canada, Germany, } \\
\text { France, UK, Saudi Arabia, Indonesia, New Zealand, } \\
\text { Greece, Trinidad, Qatar, Jordan and Ecuador, } \\
\text { Singapore and Malaysian power grids. Oman and } \\
\text { Guatemala }\end{array}$ \\
\hline 5 & Lorson and Toubro & $\begin{array}{l}\text { Qatar, UAE, Iraq, Oman, Kuwait, Sudan, Sri } \\
\text { Lanka, Mozambique, Yemen, Uzbekistan, } \\
\text { Bahrain, Nepal, Russia, Saudi Arabia, } \\
\text { Australia, Malaysia, Mauritius, Bangladesh, } \\
\text { Maldives, Bhutan, Suriname, Jordan, } \\
\text { Kenya, Tanzania, Germany, West Indies }\end{array}$ \\
\hline 6 & Puni Lloyd & $\begin{array}{l}\text { Asia Pacific, South Asia, Middle East, the Caspian, } \\
\text { Africa, China and Europe }\end{array}$ \\
\hline
\end{tabular}




\begin{tabular}{|c|c|c|}
\hline 7 & Bharat Forge & $\begin{array}{l}\text { USA, Germany, Sweden, Scotland, North America, } \\
\text { China, Scotland, Europe, Asia (India \& China). }\end{array}$ \\
\hline 8 & Mahindra \& Mahindra & $\begin{array}{l}\text { China, Sri Lanka, Bangladesh, USA, Iran, Mali, Brazil, } \\
\text { South America }\end{array}$ \\
\hline 9 & Tech Mahindra & $\begin{array}{l}\text { Americas, Europe, Middle-east, Africa and Asia- } \\
\text { Pacific }\end{array}$ \\
\hline 10 & Reliance Industries & $\begin{array}{l}\text { Malaysia, Tanzania, Uganda, Kenya, Central and } \\
\text { East Africa }\end{array}$ \\
\hline 11 & Suzlon Energy & $\begin{array}{l}\text { USA, Australia, Europe, China, Brazil, Korea, } \\
\text { Nicaragua }\end{array}$ \\
\hline 12 & ONGC & $\begin{array}{l}\text { Venezuela, Cuba, Columbia, Brazil, Libya, Nigeria, } \\
\text { Nigeria JDZ, Congo, Sudan, Egypt, Russia, Myanmar, } \\
\text { Vietnum, Turkmenistan, Iran, Qatar, Irag, Syria. }\end{array}$ \\
\hline 13 & Hindalco & 40 numbers of countries \\
\hline 14 & Essar Steel & Indonesia, Vietnam, Spain, \\
\hline 15 & Jindal Stainless & UK, Dubai, Indonesia, Italy, Turkey. \\
\hline 16 & Tata Steel & $\begin{array}{l}\text { North America, Latin America, Singapore, Thailand, } \\
\text { Oman, South Africa, Australia, Mozambique, lvory } \\
\text { Coast, Japan, Scandinavia, China, Turkey, Western } \\
\text { Africa, Western Europe, CIS, CEE, India, South East } \\
\text { Asia. }\end{array}$ \\
\hline
\end{tabular}

Source: Compiled from Annual Reports

The spreads are basically indicating the presence due to collaboration, strategic acquisition, joint venture, branch existence and operation and other form of alliances with the entities of other than the India. Today, many Indian MNCs are becoming globally reputed like ONGC, IOCL, RIL, and TATA Steel.

\section{Presence by Business Operation}

Indian MNCs do not have only the geographical spread. In the country they possess qualitative as well quantitative business presence which can be understood from the director's report of select corporations.

Punj Lloyd group is a diversified global conglomerate providing Engineering \& Construction services in Oil \& Gas, Infrastructure and Petrochemicals, and 
with interests in Defence, Aviation, Marine and Upstream sectors. Puni Lloyd has established it as a globally reputed EPC (engineering, procurement and construction) group, with over 14,500 employees, 16 offices worldwide, and projects across Asia Pacific, South Asia, Middle East, the Caspian, Africa, China and Europe. Besides the EPC execution, it has been in the news for diversified services i.e. Aviation, Defence, Upstream and Offshore. It has been progressing at a rapid clip and its performance in fiscal year 2008 speaks for itself.

Hindalco has grown into the largest vertically integrated aluminium company in the country and among the largest primary producers of aluminium in Asia. Its copper smelter is today the world's largest custom smelter at a single location. Hindalco in the line of its vision to be a premium global conglomerate with a clear focus at each business level, its geographic reach has far expanded. The year 2007-08 has indeed been a landmark year consequent to major acquisitions. Chairman expressed 'today our Group is a US $\$ 24$ billion corporation with a market cap in excess of US\$ 23 billion, anchored by a committed 100,000 workforce belonging to 25 nationalities, representing 20 countries across 5 continents. We are all glued together by a common set of values - Integrity, Commitment, Passion, Seamlessness and Speed'.

In the world of steel business, Jindal Stainless Limited (JSL) is a celebrity organization in steel sector. Jindal, ranked fourth amongst the top Indian business houses in terms of assets, the group today is a US $\$ 10$ billion conglomerate. Jindal continues to put its endeavor to move on its strategic path of becoming the most cost competitive global stainless steel facilities with high level of upstream and downstream integration. During the year, it has achieved financial closure for Phase II of its Orissa Project envisaging setting up of 0.8 million tons integrated stainless steel facilities. The capital expenditure initiated couple of years back focusing of expansion of stainless steel facilities at Hissar as well as Ferro Alloys and Thermal Power project in Orissa, reached a major milestone towards achievement of its long term strategic goals. Despite all odds, the company during the financial year 2007-2008 sustained a marginal increase in gross revenue of Rs. 5698.20 crore.

Reliance industries Limited [RIL] continues to be recognized all over the world for its global competitiveness. The company has fortified its position as India's largest exporter. As part of ensuring its global leadership in the 
polyester business, it has also commissioned a 730,000 tonnes per annum PTA plant at Hazira. In the coming years i.e. 2009 onwards, it will endeavour to strengthen our global leadership position in polyester by building and acquiring new capacities at very competitive costs. It will increase its focus on capturing the significant growth opportunities in both apparel and nonapparel segments. It expects that the march towards global leadership in the polymer business continues to be unabated. During the year 2007-08, it has increased its annual capacity of polypropylene by 280,000 tonnes at Jamnagar.

\section{Domestic vs. Overseas Presence}

The picture of domestic and overseas presence of these MNCs is not clear from above which is based on annual reports. For more objectives interpretation, author selected three criterions- they are - Revenues, Assets and Employees. The data published in the work of Bhuva. Rajib (2008), title -Global 50 Listing: Overseas Exposure were selected for three variables for select MNCs to compared the overseas as well as domestic presence by percentage in the figure-1. Ranbaxy, a Pharmaceutical company showing its overseas revenue 80 percent and only 20 percent was its domestic revenue. Next, Puni Loyd, earned overseas revenue 67.5 percent, and Bharat Forge earned 54.5 percent of total revenue as the overseas revenue. All other MNCs (except threes) the percentage of overseas revenues of total revenues earned by concerned MNCs was lesser than percentage of domestic revenue.

For comparing domestic and overseas assets based of the corporation, data for 13 numbers from select company found were compared. Among the 13 companies, Sun Phrama and Suzlon Energy showed higher level of overseas presence through their asset base. Sun Pharma's position for the presence of overseas assets in highest i.e. 51 percentage. The Suzlon holds overseas assets 46.3 percent of total assets. Domestic assets of other than this two were above the range of 68.8 percent of total assets. Essar steel holds 97.2 percent of total assets as the domestic assets.

Finally, compared the portion of domestic and overseas employees (in the figure-1) for the referred MNCs. Bharat Forge, a engineering sector enterprise possessing 47.2 percent of total employees are overseas employees; Crompton Greaves posses 36.3 percent of total employees as overseas employees for their operation. Next, Ranbaxy a pharmaceutical corporation 
posses 31.7 percent of total employees is overseas employees. Companies other than this three are showing overseas presence based on the strength of their domestic employees.

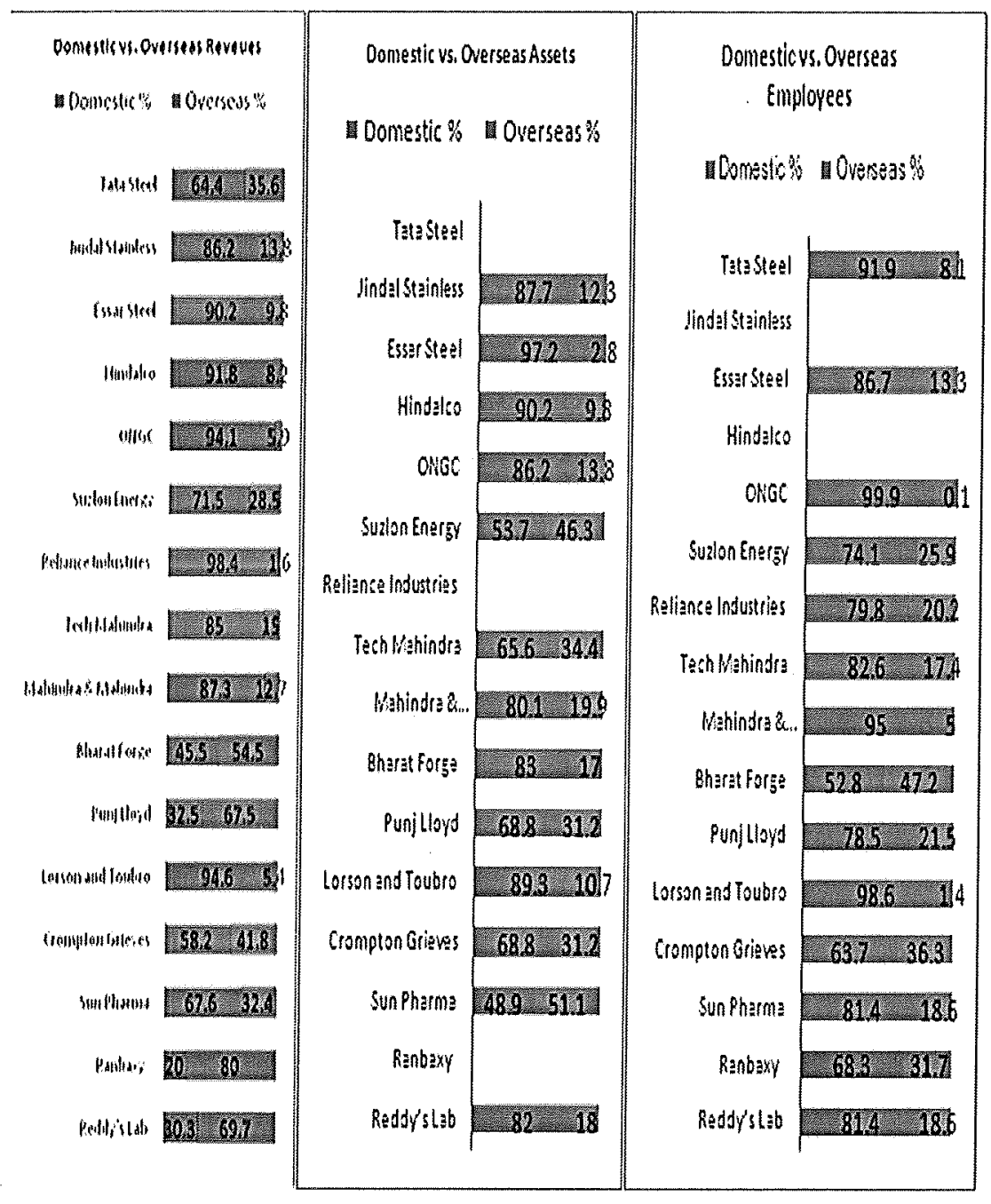

Fig. 1: Dividend Chart

Source: Compiled from Annual Reports 


\section{Convergence of Core Strategies}

The strategy generally brings about earning a superior return over the longer run. Porter explains the essence of strategy as, 'is then about figuring out which set of needs you are going to meet in your company, which are different from the needs that you competitors are trying to meet'. Whether these MNCs are adopting similar strategies or are there convergence of core strategies for operation and business expansion is the question need close observation.

Jindal Steel Limited (JSL) deployed capacity expansion and increasing operations footprint across the globe forms the fulcrum of JSL's growth line going forward. Growth, end-to-end integration \& sustained value-creation characterize JSL's leadership in India; for the largest integrated producer of international grade stainless steel, change is in the air to further expand its stronghold position in the domestic as well as global expanses. Fortifying the company's unique backward \& forward integration strength, JSL looked beyond horizons and pushing the envelope towards finding solutions \& answers to challenges faced yester year, for a shining forward.

Hindalcos' core values were 'Integrity, Commitment, Passion, Seamlessness and Speed'. Cost Competitiveness reflected through its strong manufacturing base and operational efficiencies; Quality through its versatile range of products serving core applications for diverse industries; and Global reach through competing in markets across more than 40 countries. The vision of Hindalco is to be a premium metals major, global in size and reach, with a passion for excellence. In the recent past Hindalco followed more aggressive dashboard for its growth aspirations. It has scaled up its ambitions exponentially. In the word of chairman 'we have embarked on major capacity expansions. Our growth has been through the organic and inorganic route. We acquired Indal - an Alcan subsidiary in India, in 2000'.

TATA Steel Ltd has understood the idea of collaborative growth is one which is particularly relevant in today's context. With a growing global market, countries, corporations, communities and people collaborating with each other to mutual benefit is a route of growth that is perhaps the most effective. The Tata Steel Group has long believed in this concept, and in the last year, has successfully entered a phase of integration with its partners in growth. Tata Steel and Corus, two companies with long proud histories, share a common business culture and a global vision for the future. And 
this shared vision has resulted in the emergence of strong synergies that have catapulted the Tata Steel Group to the position of the world's fifth largest manufacturer of steel, with 82,700 employees across four continents. Tata adopted manufacturing strategy for determining greater productivity leading to increased output and market size; Procurement strategies for economies of scale leading to cost reduction through combined buying; adopted Research and Development (R\&D) for cross fertilization of R\&D capabilities and operational best practices, leading to greater innovation and operational efficiencies; and finance and corporate restructuring strategies for re-organization and refinancing. In addition to manufacturing and technology development, TATA has been made much progress in areas like Information Technology, Human Resources, and other support functions. These were expected to result in synergies much beyond the initial target of USD 450 million. The Tata Steel Group's vision was actualized through a strategy of increasing the quality of earnings from its existing assets coupled with strategic growth.

Reddy's Lab, adopted lean management for manufacturing operations, discovery research and building new capabilities for R\&D. Over the past few years, the company has been developing the different building blocks of future growth. Some of these have been: creating a lean manufacturing organization; strengthening Dr. Reddy's position in existing markets and developing new geographies; building more infrastructure to drive higher levels of output; creating a faster and more focused product development process; building wider technical capabilities; leveraging the new acquisitions; optimizing efforts across the Company through bestin- class IT and ERP systems; and, most importantly, bringing all these together by creating a commonly aligned organization.

In the directors report 2007-08 of Reliance industries mentioned that as a part of their overall strategy to overcome the challenges in the domestic market and to increase our presence in the export markets as a prelude to the impending commissioning of the new Greenfield refinery, the director delighted to inform to shareholders that they have exported $57 \%$ of its aggregate refinery product volumes in the quality conscious global markets. Its new value creation efforts in the domains of exploration and production, organized retailing and the Greenfield petroleum refinery and polypropylene plant in the Special Economic Zone at Jamnagar are progressing as per schedule. Punj Loyd, through the strategic investments, it has forayed into Aviation, Shipbuilding, and Real Estate and Defence sector. 


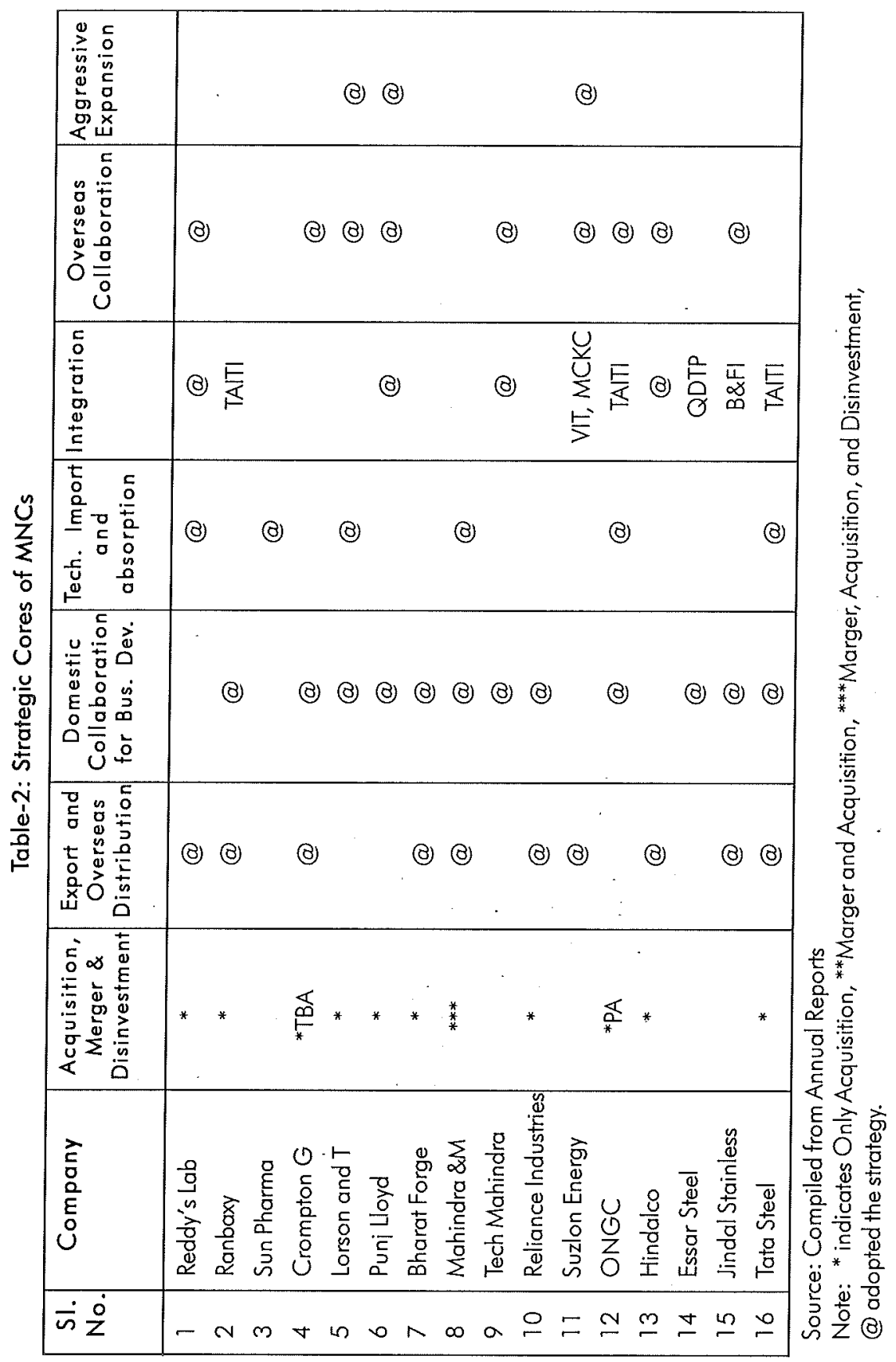


For understanding objectively and more lucidly the convergences of core strategies a few the variables, they are- Acquisition and Merger; Export and Overseas Distributions; Domestic Collaboration for Business Development; Technology Imports and Absorption; Integration; and Aggressive Expansion were selected for explaining comprehensively. In the table-2 convergence of core strategies of select corporations are shown tabulated format of the facts collected from the annual reports. In the table the boxes were filled up from very minute observation of various records and published evidences of the MNCs. Last column of the table for variable aggressive expansion strategy appeared as a common core for only three MNCs from the select groups. Export and overseas distribution; domestic collaboration; Overseas collaboration; and Acquisition are the strategies having convergence.

Crompton Greaves adopted acquisition on the basis of technology *(TBA) for business expansion. ONGC is adopting Project acquisition * $(\mathrm{PA})$ as the business expansion strategy. Suzlon Energy has been adopting Vertical Integration (VIT) and Manufacturing Capability for Key Components (MCKC). Jindal Stainless adopted backward and forward integration (B\&FI) of technology and business as the strategy for business expansion. Essar Steel integrated the Quality, Delivery, Technology and Price as its main business strategy. Ranbaxy, ONGC and TATA integrated Technology and IT integration (TAITI) with whole business operation.

\section{Corporate Consciousness for Society}

Chair Person of Jindal Steel Limited (JSL) addressed to shareholders in our 38 years of success scripted journey so far, Jindal Stainless has consistently aimed to go beyond the function of business leadership, and be sustained wealth-creators in an ever more competitive global economy; thus ensuring its focus remains on social \& economic developmental needs of the people $\&$ region we operate in'. As it made significant progress and capital investments are improving our manufacturing capabilities and capacity expansions in respective accordance of Long-Term and Medium-Term Business Plan strategies; JSL also invested in environmental conservation and improvements.

Puni Lloyd (PL), building infrastructure across nations and enriching communities worldwide, we take pride in being a true global citizen. It connects with and shape the communities where we operate. As a global citizen, it utilizes local sources for materials and services. Through jobs, 
training, and education, Punj Llyod contributes to the economic progress of every country where they do their business. And it strives to maximize sustainability so as to honour and support each place where we work. The chair of PL assured the share holders that any and every project we undertake ultimately benefits the common person, making his or her life easier. Concurrently, at Puni Lloyd, they believe in giving back to society and strengthening individuals and communities where we have operations. Puni Lyod has understood the benefits of highways in enabling connectivity and consequently enhancing quality of life cannot be overstated 'oil and gas is vital for a nation's growth and improved industrial activity and is a sector which comprises a significant portion of their revenue'. Among other benefits, they provide premium housing and commercials to our high end clients at par with international standards so as to provide benchmark quality standards and a luxurious lifestyle. In a burgeoning economy this is increasingly becoming the need of the hour.

Tata's benchmark in corporate citizenship involves providing a safe working place, respecting the environment, caring for its communities and demonstrating high ethical standards. The Group's ambition of becoming the benchmark of the industry in corporate citizenship has been translated into clear goals and actions. The Group is committed to creating a safe working environment for everyone. Whilst it has achieved significant progress over the last few years, it has a goal to improve further, with lost time injury frequency improving to 0.4 by 2012 to becoming best in class. New actions would be introduced in the areas of high hazard facilities, occupational safety and health and a review of the management system and organization is on the agenda Tata Steel. In terms of communities, the Tata Steel Group promotes and encourages economic, environmental, social and educational development. In India, its focus is on fulfilling basic requirements including healthcare, food security, education and income generation through the development of rural infrastructure, empowerment and community outreach programmes. In Europe, it is actively involved in a broad range of community initiatives, such as being premier sponsor of the British Triathlon.

In the annual report 2007-08 of Reddy's Lab "our values and touches almost all aspects of our company, from our purpose and values, marketplace and innovation, workplace safety, people practices, environment management, human rights to community contribution. We publish our Corporate Sustainability Report annually giving a detailed account of our 
economic, environmental and social performance". Safety, health and environment (SH\&E) policy stating our commitment to the principles of sustainability and SH\&E. Programs are in place to implement various elements of this policy. It views the environmental management from the point of resource conservation. Continuous efforts are being made to reduce the residual environmental impact of our processes. Well designed effluent treatment facilities based on the state of the art membrane technology coupled with multiple effect evaporators and spray dryers help CTO units to recycle the entire industrial effluent to be reused after treatment in the plant. Livelihood creation strengthening education - Dr. Reddy's foundation acts as a catalyst of change that fosters, develops and promotes initiatives at individual, group and organizational.

As part of RIL efforts to benchmark our performance globally, they have initiated publication of the Corporate Sustainability Report. RIL published its second sustainability report aligned to Global Reporting Initiative (GRI) framework. GRI has accorded "GRI Checked A+ level" rating for the second report. This is a unique feat and reaffirms the fact that the company has distinguished itself as a leader in the field of corporate sustainability reporting. Reliance will remain firmly committed, as always, in maximizing shareholder value. Their new initiatives in organized retailing, oil and gas exploration and production and infrastructure will start generating significant shareholder value in the next few years. Along with these, they will focus on consolidating and growing our leadership position in their existing businesses. This will enable them to excel in delivering superior shareholder value. They have always betted on their youth who have delivered results. They realized that youthfulness and dynamism fuels reliance's growth plans.

ONGC, a Fortune Most Admired Company (2007) spearheading the United Nations Global Compact- World biggest corporate citizenship initiative to bring industry, UN Bodies, NGOs, Civil Societies and Corporate on the same platform. The company considers Education is the most important of ONGC's CSR verticals. Suzlon Energy, a Leader of Wind Energy (LWE) committed for millennium achieving the millennium development goals.

\section{Global Consciousness}

The global consciousness of corporations can not be discussed in isolation to social consciousness. Hence, before global consciousness of MNCs the above section dealt to streamline the blurred issue. Considering the 


\begin{tabular}{|c|c|}
\hline 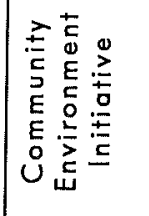 & 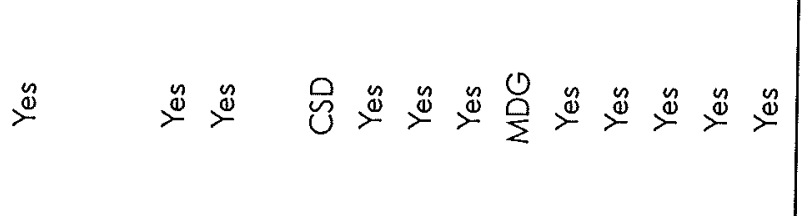 \\
\hline 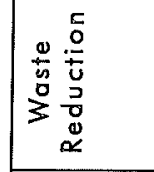 & 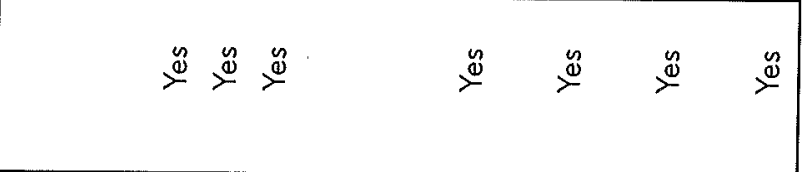 \\
\hline 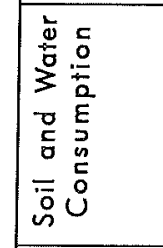 & 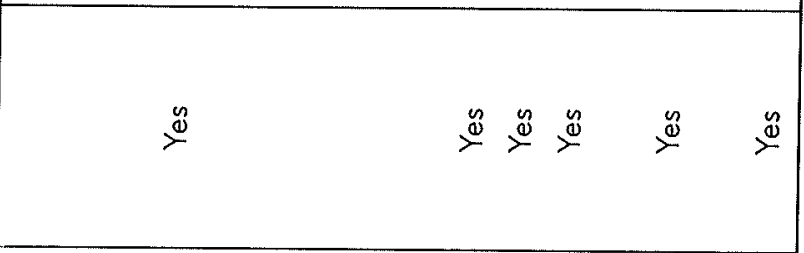 \\
\hline 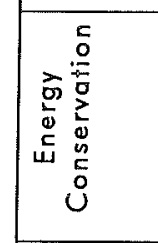 & 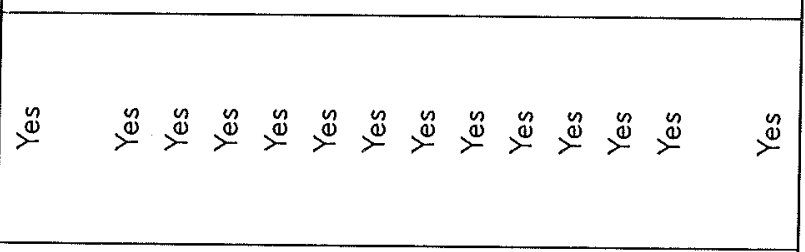 \\
\hline 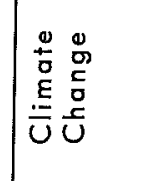 & 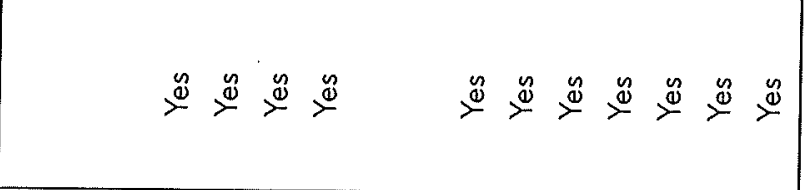 \\
\hline 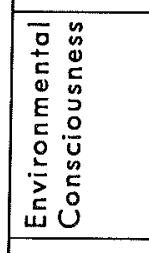 & 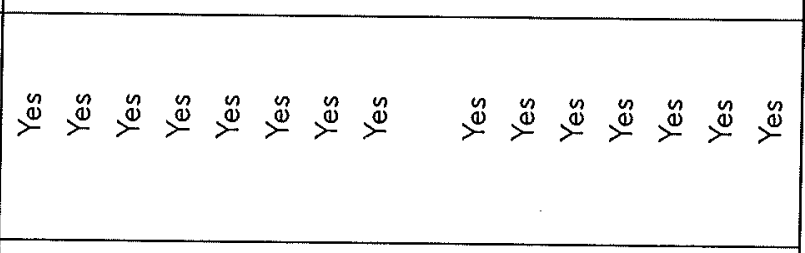 \\
\hline 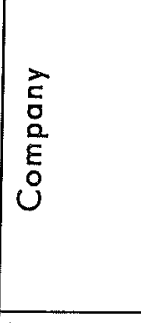 & 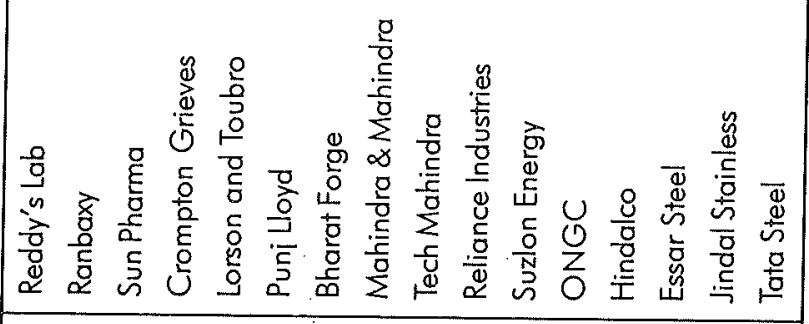 \\
\hline$\dot{s i z}$ & 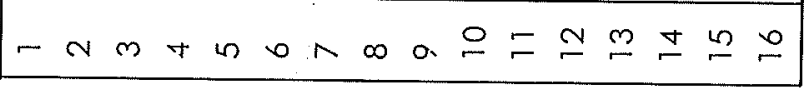 \\
\hline
\end{tabular}


inadequacy of interpretation in the table-3 was prepared to explain the global consciousness of referred companies. In the table the initiatives which have been taken as a result of global concern as well as published in the annual reports of concerned company were inserted. Majority of MNCs are explicitly indicated that they are environmentally consciousness. Technology based corporations, iron and steel companies, energy sectors MNCs are much corned to climate change of the globe. The indications of energy conservation efforts were also found for majority entities. Community based environment initiatives were adopted by the majority of MNCs. Beyond the implicit concerns Bharat Forge and Suzlon Energy have evidenced the commitment to sustainable development [CSD] and millennium development goals [MDG]. Though the soil and water consumption and waste reduction are part of the global consciousness but in some cases these were not explicit goals and not integrated to their CSR verticals.

\section{Directions and Readiness for Future}

Like streams of water that flow smoothly when moving slowly, but irregularly when moving fast, the events of our 21 st century world are becoming swifter, more turbulent, and harder to predict. The unexpected is becoming commonplace. We live in an age of uncertainty. As the world becomes less certain; scalable efficiency is losing its way. Yet our economy is chock-ablock with businesses that exist to maximize efficiency at scale. In yester time businesses presuming predictability in order to push out mass produced products supported by mass marketing programs. Businesses relying on command and control in a world that's increasingly difficult to command or control. Businesses are losing their leadership positions at an ever-faster rate because they continue to push in a world gone pull. The death of command and control has been greatly exaggerated for years now. The businesses need a new rationale for our biggest private and public sector institutions - to re-imagine them in line with the world around us. Rather than scalable efficiency, we need scalable connectivity, learning, and performance. Rather than push, we need institutions that pull. In this conceptual backdrop, explicit announcement and readiness of the MNCs are rare in the discussion of corporate boards. It indicates, to manage the future global businesses under the conceptual, policy, flexibility, and risk ridden tempest the Indian MNCs are yet to think in terms of emerging concepts of business and future business globe. 


\section{Findings and Possibility for Critical Test}

There is always having enormous rooms for the critical test of findings of this type of study if the findings are judiciously and systematically arranged for scientific observation. The main findings of this paper are-

- The geographical spread of few Indian MNCs has reached over fourty numbers of countries of the globe. A very less numbers Indian MNCs having it business presence in Russia and in African Countries.

- The MNCs which are showing wide spread in the global business are holding the positions of either as largest exporter or largest producer or global leader, or world celebrity among the global business.

- Indian MNCs are showing overseas presence not on the strength of overseas assets holdings but on overseas revenues, and on the strength of domestic employees.

- Acquisitions, domestic and overseas collaboration for business development are the core strategy of Indian MNCs.

- Absorption, integration, export and overseas distributions are having strong possibility of convergence with core strategies, and aggressive expansion is a less preferred strategy for Indian MNCs.

- Commitment to sustainable development and environmental consciousness is both implicit as well as explicit concern of Indian MNCs.

- The study indicates that Indian MNCs are following push up approach and institutional format; not yet adopted pull up approach or pull up institutional format.

These findings are based on the study of only 16 numbers of MNCs would inherently put up with some limitations. The paper explained MNCs presence with the help explanation of geographic and economic presence. For explaining the spreads of select MNCs author meet the countenance of inadequacy of expression in the format of advanced classifications of reasons of MNCs presence in the different parts of the world. In explaining the domestic presence with the subjective information from published annual reports, author first to tolerated the non-uniformity of data and languages of annual reports, as a result the must have to tolerate the same while in reading. Hence, about three corporations, author has not interpreted the 
facts in the similar spirit. About the global consciousness of Indian MNCs and for the strategic cores the authors had to adopt a common approach in interpretation and in selection of the common variables. Since the data sources are secondary for this study still author has attempted to achieve the objective under qualitative framework of research design under these limitations.

The study indicates lot of research clues to researchers interested for operations of MNCs in the present global business blizzard. Since, the business world is under the paradigm shift of management theories replaced by the theories of flexibility, self renewals capability, pull up approaches; hence future researcher can examine operation MNCs under these approaches. By taking sufficient time, resource, budget and sufficient sample of Indian MNCs which are having the global presence further researcher would be able fill the research and knowledge gaps in this vertical.

\section{References}

1. Ahmed. Syed Zamberi and Kitchen. Philip J. (2008), Transnational Corporation from Asian developing countries: the Internationalization characteristics and business strategies of Sime Darby Berhad; International of Business Science and Applied Management, Vol.3. Issue. 2, 2008. PP. 22-36.

2. Barman. A \& Singh R (2009), Managing HR for International Business- Break the Walled Medievalism, Confernece Proceeding, $2^{\text {nd }}$ International Conference on Leadership and its Role in Preparing the Unprecedented Change, May $23^{\text {rd }}$ to $24^{\text {th }}$ May'2009; sponsored by Central and East European Management Development Association, organized by Institute of Productivity and Management, Ghaziabad, New Delhi. Edited by Anita Methew (Book Published by Excel Publisher) PP. 333-345.

3. Bhuva. Rajib (2008), Global 50 Listing: Overseas Exposure; Outlook Business, Feb 23, 2008, PP. 52-53.

4. ERM India Report, at http:// wnw. conference-board.org/publications; browsed on 5th Jan 2009.

5. Hill. Lilian H. (2006), Global Consciousness of Human Resource Development and Organization Development Practitioners; Virginia Commonwealth University, USA

6. Mazumdar. Surajit (2008); The analysis of business Groups -Some Observations with Reference to India; ISID, Working Paper, 2008/11; December'2008.

7. Munga. Rachna(2008), End of the Indian Outbound Story?, Business Today, November'10. 2008; PP. 84-86. 
8. Porter. Michael; Sound long-term strategy is key, particularly in a crisis: Harvard's Michael Porter; at http://www.insead.edu/ retrived on 30 April 2009.

9. Pradhan. Jaya Prakash (2008); South-South Investment in Infrastructure -The Operation of Indian Firms in Developing Countries, ISID, Working Paper, 2008/09, August' 2008.

10. Saliola Federica, Zanfei Antonello(2009), Multinational firms, global value chains and the organization of knowledge transfer; Research Policy 38 (2009) 369-381

\section{Published Annual Reports (Hard Copy)}

1. Reliance 2007-08

2. Bharat Forge 2007-08

3. ONGC 2007-08

\section{Websites visited to download the Annual Reports.}

1. http:/www.jindalstainless.com/profile.html

2. http://www.tatasteel.com/advsearch.asp

3. http://www.sunpharma.com/sunpharma-products/sunpharma-formulation/index.php

4. http://www.punjlloyd.com/subpage.php?opt=0\&page_cat $=1$

5. http://www.bharatforge.com/company/global_presence,asp

6. http://www.adityabirla.com/our_sectors/\#aluminium

7. http://www.larsentoubro.com/lntcorporate/ Default.aspx? res $=$ P_CORP AABT DCOR

8. hHp://www.ranbaxy.com/index.aspx

9. http://www.kpmg.com 